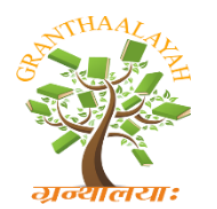

Science

\title{
STUDY ON CLINICO-ETIOLOGICAL CORELATION AND OUTCOME OF VIRAL MENINGOENCEPHALITIS IN PEDIATRIC AGE GROUP IN A TERTIARY CARE CENTRE
}

\author{
Leena Das ${ }^{1}$, Mangal Charan Murmu ${ }^{2}$, Bijaylaxmi Jena ${ }^{3}$ \\ ${ }^{1,2}$ Associate Professor, Department of Pediatrics, S C B Medical College, Cuttack, Odisha, India \\ ${ }^{3}$ Resident, Department of Pediatrics, S C B Medical College, Cuttack, Odisha, India
}

\begin{abstract}
Meningoencephalitis remains the most significant cause of childhood deaths indeed a more measure cause of long term neurological handicap in children. Herpes simplex virus (HSV) encephalitis is recognized worldwide as the most frequent infectious encephalitis and the only one with a validated specific treatment. The incidence of viral encephalitis is 3.5-7.4 per 100,000 people per year. Aim \& objectives: To study the demographic profile, etiological agent, clinical presentation, investigation findings and outcome of viral mengigoencephalitis in children. Material \& Methods: The study was conducted in the pediatric department of SCB Medical College, Cuttack Odisha. Result: Highest incidence was observed in 1-5 years age group followed by 6-14 years. Males are more affected than Female. Highest number of cases occurred in summer season $(45.2 \%)$. The common symptoms were fever (97.6\%), irritability $(80.9 \%)$, refusal to feed $(80.9 \%)$, vomiting $(80.9 \%)$, altered sensorium $(76.1 \%)$, headache $(61.9 \%)$, convulsion $(52.3 \%)$. The common signs observed were temperature $>100.4^{\circ} \mathrm{F}(94.1 \%)$, meningeal sign $(52.3 \%)$, GCS (Glasgow Coma Score) < 7 (52.3\%), hypotension (50\%), focal neurological deficit (52\%).Viral marker were detected in $47.7 \%$ of cases. HSV (Herpes Simplex Virus) was common agent found among the positive viral marker detected. Conclusion: Viral mengingoencephalitis is a major health problem due to high morbidity and mortality. Early diagnosis is often difficult due to low incidence of disease specific signs. Detection of viral antibody is done by cerebrospinal fluid (CSF) Ig M \& Ig G. PCR(Polymerase Chain Reaction) method is suggested as a better option which has more sensitivity and specificity and gives a rapid diagnosis.
\end{abstract}

Keywords: Meningoencephalitis; Herpes Simplex Virus; Polymerase Chain Reaction.

Cite This Article: Leena Das, Mangal Charan Murmu, and Bijaylaxmi Jena. (2018). "STUDY ON CLINICO-ETIOLOGICAL CORELATION AND OUTCOME OF VIRAL MENINGOENCEPHALITIS IN PEDIATRIC AGE GROUP IN A TERTIARY CARE CENTRE." International Journal of Research - Granthaalayah, 6(5), 380-390. https:// doi.org/10.29121/granthaalayah.v6.i5.2018.1466. 


\section{Introduction}

Meningoencephalitis remains the most significant cause of childhood deaths indeed a more measure cause of long term neurological handicap in children. HSV encephalitis is the most common form of viral encephalitis and has an incidence of 2-4 cases per 1 million population per year and accounts for $10 \%$ of all cases of encephalitis in the United States [1]. The annual incidence of viral encephalitis is most likely underestimated, especially in developing countries, because of problems with pathogen detection [2]. Japanese encephalitis (JE) affects at least 50,000 individuals per year. In a a study from Finland by Rantalaiho T et al (1991) the incidence of viral encephalitis in adults was 1.4 cases per 100,000 persons per years. HSV was the organism most frequently identified as the cause (16\%), followed by VZV (5\%), Mumps virus (4\%) and Influenza A virus (4\%) [3]. According to Long SS et al the clinical hallmark of acute encephalitis is the triad of fever, headache and altered mental status. Most of the patient with viral encephalitis presents with the symptoms of meningitis (fever, headache, neck stiffness, vomiting) followed by altered consciousness, convulsions and sometimes focal neurological signs, signs of raised intracranial pressure or psychiatric symptoms. There may be an association with history of infection elsewhere in the body [4]. Subacute sclerosing panencephalitis is a late complication of measles and presents four to ten years after the initial infection. Progression may be slow or rapid with personality change, dementia, seizures, ataxia and death. Progression of rubella panencephalitis is similar. Complications of viral meningoencephalitis are not infrequent, can develop early in the course of illness. Acute complication includes seizure, increase ICP, Coma, infarction, focal neurological deficit, ventriculitis. Long term sequelae are visual impairment, hearing defect, persistent seizure, behavioral disorder, mental retardation and developmental delay.

Thus, for reduction of high mortality and morbidity of viral meningoencephalitis in children there is a clear need for analyzing the clinical parameters of the disease. At the present time effective viral vaccines for Polio, Measles, Mumps, Rubella and Varicella are widely available but nevertheless prudent clinical judgment and timely intervention are highly warranted.

Keeping all these in mind, the present study was undertaken to determine the possible clinical and investigative clue of disease etiology as well as identifying those presenting clinical parameters which correlate with disease outcome.

\section{Aim and Objectives}

To study the demographic profile, etiological agent, clinical presentation, investigation findings and outcome of viral mengigoencephalitis in relation to death, recovery and sequelae in children.

\section{Methodology}

After obtaining clearance from the institutional ethical committee the study was conducted in the pediatrics department of S C B Medical College, Cuttack. This is a prospective study done over a period of September 2015 to August 2017.All the babies admitted through OPD or emergency department with suggestive signs and symptoms of viral meningoencephalitis like fever, refusal to feeds, headache, vomiting, convulsions altered sensorium, lethargy were admitted and thorough systemic examination, biochemical and microbiological examinations of blood and CSF were done and those patients satisfying the inclusion criteria were included in the study. 
Inclusion Criteria: i. age between 1 month to 14 years. ii. C S F showing protein $50-200 \mathrm{mg} / \mathrm{dl}$, sugar normal or $<40 \mathrm{mg} / \mathrm{dl}$, cells $<1000 / \mathrm{cmm}$.

Exclusion Criteria: i. Neonatal age group 0-1 months baby, ii. Those with clinical suspension and not evaluated and leave against medical advice. iii. Parents who did not gave consent for the study. iv. Alternative diagnosis was made during the course of hospitalization. All the cases included in the study were treated empirically with antiviral agents and as needed with antibiotics. Appropriate supporting care including attention to fluids, electrolytes, ventilations and parenteral nutrition was provided. 42 cases were included in our study after the criteria were satisfied.

All the studied cases were analyzed for various clinocobiochemical parameters in terms of outcome of the disease. CSF was cultured on specific media. Other investigations included complete blood counts, Chest X-rays, renal and liver function test, electrolytes, blood and urine culture. C-reactive protein (CRP) was determined in serum and categorized as positive or negative. HSV-1 \& HSV-2 IgM detection was done by HSV-1\& HSV-2 IgM fast EIA KIT. PCR, an invitro DNA amplification procedure in which millions of copies of a particular sequence could be produced within few hours. In this method detection of HSV-1, HSV-2 \& VZA DNA were done in acute phase of disease.

Statistical analysis was done by chi-square test whenever applicable. $\mathrm{P}$-value of $<0.05$ was considered to be significant.

\section{Observation}

Table 1: Age and Sex distribution

\begin{tabular}{|l|l|l|l|l|}
\hline Age & No of cases & Male & Female & Percentage in total \\
\hline$<1$ year & 3 & 2 & 1 & 7 \\
\hline 1-5 year & 20 & 13 & 7 & 48 \\
\hline 6-14 year & 19 & 9 & 10 & 45 \\
\hline
\end{tabular}

The incidence of viral meningitis in our study $7 \%$ were infant, $48 \%$ were from $1-5$ years and $45 \%$ were included in 6-14 years of age group.

Table 2: Seasonal variation

\begin{tabular}{|l|l|}
\hline Summer & 19 \\
\hline Rainy & 15 \\
\hline Winter & 8 \\
\hline
\end{tabular}

Our study showed highest seasonal occurrence of viral meningoencephalitis in summer $45.2 \%$ cases, followed by $36.8 \%$ in rainy and $19 \%$ in winter.

Table 3: Symptoms Observed

\begin{tabular}{|l|l|l|l|}
\hline Symptoms & Survived $(\mathbf{n = 3 4})$ & Died $(\mathbf{n = 8})$ & Total $(\mathbf{n = 4 2})$ \\
\hline Fever & 34 & 7 & 41 \\
\hline Vomiting & 27 & 7 & 34 \\
\hline Convulsion & 22 & 6 & 22 \\
\hline
\end{tabular}




\begin{tabular}{|l|l|l|l|}
\hline Parotid swelling & 12 & 0 & 12 \\
\hline Irritability & 27 & 7 & 34 \\
\hline Headache & 19 & 5 & 26 \\
\hline Refusal to feed & 27 & 7 & 34 \\
\hline Altered sensorium & 24 & 8 & 32 \\
\hline Lethargy & 3 & 2 & 5 \\
\hline
\end{tabular}

The fever was the commonest symptoms in all groups with total incidence of $97.6 \%$ followed by irritability $(80.9 \%)$, refusal to feed $(80.9 \%)$, altered sensorium $(76.1 \%)$, headache $(61.9 \%)$, convulsion $(52.3 \%)$, parotid swelling $(28.7 \%)$, lethargy $(11.9 \%)$.

Table 4: Sign observed

\begin{tabular}{|l|l|l|l|}
\hline Signs & Survived $(\mathbf{n}=\mathbf{3 4})$ & Died $(\mathbf{n}=\mathbf{8})$ & Total $(\mathbf{n}=\mathbf{4 2})$ \\
\hline Temp $>100.4 \mathrm{~F}$ & 32 & 6 & 40 \\
\hline RTI & 8 & 4 & 12 \\
\hline GCS $<7$ & 15 & 7 & 22 \\
\hline Meningeal sign & 16 & 6 & 22 \\
\hline Bulging fontanels & 3 & 5 & 8 \\
\hline Weakness of limbs & 5 & 2 & 7 \\
\hline Papilledema & 5 & 6 & 11 \\
\hline Hypotension & 14 & 7 & 21 \\
\hline Focal neurological deficit & 17 & 5 & 22 \\
\hline
\end{tabular}

The signs observed temperature $>100.4 \mathrm{~F}$ was most common sign in $32(94.1 \%)$ children, followed by Meningeal sign in $52.3 \%$ children, GCS $<7(52.3 \%)$, hypotension (50\%), focal neurological deficit $(52 \%)$.

Table 5: Biochemical parameter

\begin{tabular}{|c|c|c|c|c|}
\hline Parameter & Levels & Survived $(n=34)$ & Died $(n=8)$ & Total $(n=42)$ \\
\hline \multirow[t]{2}{*}{ Cell count } & $<50 / \mathrm{cmm}$ & 18 & 8 & 26 \\
\hline & $50-1000 / \mathrm{cmm}$ & 16 & 0 & 16 \\
\hline \multirow[t]{2}{*}{ Sugar } & $<40 \mathrm{mg} / \mathrm{dl}$ & 14 & 2 & 16 \\
\hline & $>40 \mathrm{mg} / \mathrm{dl}$ & 20 & 6 & 26 \\
\hline \multirow[t]{2}{*}{ Protein } & $<45 \mathrm{mg} / \mathrm{dl}$ & 12 & 3 & 15 \\
\hline & $>45 \mathrm{mg} / \mathrm{dl}$ & 62 & 5 & 27 \\
\hline \multirow[t]{2}{*}{ Viral marker } & $+\mathrm{ve}$ & 12 & 8 & 20 \\
\hline & $-\mathrm{ve}$ & 22 & 0 & 22 \\
\hline $\mathrm{Hb}$ & $<10 \mathrm{gm} \%$ & 1 & 5 & 6 \\
\hline TLC & $>1100 / \mathrm{cmm}$ & 2 & 5 & 7 \\
\hline Serum CRP & $>6 \mathrm{mg} / \mathrm{L}$ & 13 & 7 & 20 \\
\hline LFT & Abnormal & 1 & 5 & 6 \\
\hline RFT & Abnormal & 2 & 6 & 8 \\
\hline \multirow{3}{*}{$\begin{array}{l}\text { CT/MRI brain } \\
\text { abnormality }\end{array}$} & Normal & 21 & - & 21 \\
\hline & Swelling of parenchyma & 3 & - & 3 \\
\hline & Infaction & 4 & - & 4 \\
\hline
\end{tabular}


On CSF study, cell count was found to be less than 50 /cumm in all patients who died and $56.3 \%$ of cases who survived. CSF sugar was found at $<40 \mathrm{mg} / \mathrm{dl}$ in $38 \%$ cases and $27 \%$ of cases were found protein value $>45 \mathrm{mg} / \mathrm{dl}$. The different hematological parameters in meningoencephalitis in our study was serum CRP $>6 \mathrm{mg} / \mathrm{L}$ most frequent (47\%), followed by TLC $>11000 /$ cumm in $16.7 \%$ of patient and $\mathrm{Hb}<10 \mathrm{gm} \%$ in $14.2 \%$ of patients. High abnormal LFT $(75 \%)$ and abnormal RFT $(87.5 \%)$ were found in cases who are died. The CT and MRI brain abnormalities in meningoencephalitis shows $75 \%$ normal, swelling of parenchyma in $12 \%$ \& Infarction in $13 \%$ of cases.

Table 6: Clinico-etiological correlation of viral meningoencephalitis

\begin{tabular}{|l|l|l|l|l|}
\hline Features & Total $(\mathbf{n = 4 2})$ & HSV(n=12) & HZV(n=11) & Others $(\mathbf{n = 1 9 )}$ \\
\hline Convulsion & $22(52.4 \%)$ & $7(58.3 \%)$ & $7(63.6 \%)$ & $8(42.1 \%)$ \\
\hline Altered sensorium & $34(100 \%)$ & $11(91.6 \%)$ & $10(90.9 \%)$ & $13(68.4 \%)$ \\
\hline Meningeal sign & $22(52.4 \%)$ & $11(91.6 \%)$ & $3(27.2 \%)$ & $8(42.1 \%)$ \\
\hline Papiledema & $11(26.2 \%)$ & $7(58.3 \%)$ & $4(36.3 \%)$ & $0(0 \%)$ \\
\hline RTI & $12(28.5 \%)$ & $4(33.3 \%)$ & $4(36.3 \%)$ & $4(21.0 \%)$ \\
\hline CSF cell count $>50 / \mathrm{cmm}$ & $16(38.0 \%)$ & $4(33.3 \%)$ & $0(0 \%)$ & $12(63.1 \%)$ \\
\hline CSF protein $>45 \mathrm{mg} / \mathrm{dl}$ & $18(42.9 \%)$ & $8(66.6 \%)$ & $7(63.6 \%)$ & $3(15.7 \%)$ \\
\hline CSF sugar $<40 \mathrm{mg} / \mathrm{dl}$ & $16(38.0 \%)$ & $1(8.3 \%)$ & $4(36.3 \%)$ & $11(57.8 \%)$ \\
\hline
\end{tabular}

In Clinical presentation of our study showed altered sensorium in 13(68.4\%) followed by convulsion \& meningeal sign each $8(42.1 \%$ ) of cases. in CSF study $>50$ cells count /cumm was found in $>50 \%$ of the group. CSF protein was high in both HZV 6(66.6\%) \& VZV 7(63.7\%) cases. Low CSF sugar was found in others 11(57.8\%) cases.

Table 7: Comparison of CSF parameters between HSV \&HZV Meningoencephalitis

\begin{tabular}{|l|l|l|l|}
\hline Features & HSV & HZV & P-value \\
\hline Mean CSF cell count & $166.36 \pm 206.68$ & $4 \pm 5.82$ & 1.00 \\
\hline Mean CSF protein & $79.82 \pm 49.15$ & $64.80 \pm 34.02$ & 0.430 \\
\hline Mean CSF sugar & $69.09 \pm 15.97$ & $54.70 \pm 22.17$ & 0.101 \\
\hline
\end{tabular}

The CSF parameters between HSV \& VZV meningoencephalitis showed no statistically significant among both groups.

Table 8: Comparison of outcome among HSV\& HZV

\begin{tabular}{|l|l|l|l|}
\hline Parameter & HSV & HZV & P-value \\
\hline Mortality & 7 & 1 & 0.0415 \\
\hline Sequelae & 4 & 2 & 0.7253 \\
\hline Deafness & 1 & 0 & 0.3276 \\
\hline Seizure & 1 & 0 & 0.3276 \\
\hline Motor incordination & 1 & 1 & 0.9486 \\
\hline Behavioral disorder & 1 & 0 & 0.3276 \\
\hline Cranial nerve palsy & 0 & 1 & 0.9645 \\
\hline
\end{tabular}

The mortality in HSV was 7(58.5\%) which was highest and statistically significant 
Table 9: Correlation of parameters who survived and died

\begin{tabular}{|l|l|l|l|l|}
\hline Parameters & Total $(\mathbf{n}=\mathbf{4 2})$ & Died(n=8) & Survived(n=34) & p-value \\
\hline RTI & 12 & 4 & 8 & 0.290 \\
\hline Altered sensorium & 34 & 8 & 24 & 0.277 \\
\hline Convulsion & 22 & 7 & 15 & 0.069 \\
\hline GCS $<7$ & 20 & 7 & 13 & 0.034 \\
\hline Intubation & 15 & 6 & 9 & 0.030 \\
\hline Duration of illness $>7$ days & 16 & 6 & 10 & 0.047 \\
\hline
\end{tabular}

Among the different parameters studied, the incidence of GCS $<7$, intubation of with respiratory failure and duration of illness $>5$ days were statistically significant among survivors and died.

Table 10: Comparison between parameters who survived and died

\begin{tabular}{|l|l|l|l|}
\hline Parameters & Died $(\mathbf{n}=\mathbf{8})$ & Survived(n=34) & p-value \\
\hline Mean CSF cell count & $16 \pm 6.72$ & $138.91 \pm 135.66$ & 0.0374 \\
\hline Mean CSF protein & $84.88 \pm 57.56$ & $59.94 \pm 35.49$ & 0.1249 \\
\hline Mean CSF sugar & $64.50 \pm 33.22$ & $61.81 \pm 28.30$ & 0.8176 \\
\hline
\end{tabular}

The mean CSF Cell count/cumm was statistically significant.

\section{Discussion}

The incidence of viral meningitis in our study $7 \%$ were infant, $48 \%$ were from $1-5$ years and $45 \%$ were included in 6-14 years of age group. SA Fattah et al [5] reported 5-18 years age group comprises the highest number $44 \%$. Our studies were similar to the finding of Aurelian L et al [6] and DeBiasi RL [7]. We observed 57.1\% were male babies and $42.9 \%$ were female with a ratio of 1.3:1. Rantakallio P et al [8] reported $28.8 \%$ were female and $71.2 \%$ were male. Similar observations were made by Sejvar JJ [9], M Ward et al [10], Cochi et al [11].SA Fattah et al [5] reported Male-Female ratio was 33:17 which is similar to our study.

Our study showed highest seasonal occurrence of viral meningoencephalitis in summer $45.2 \%$ cases, followed by $36.8 \%$ in rainy and $19 \%$ in winter. Chalrs G, Prober and Laurl Dyner et al [12] show most cases in temperate climate during the summer and early rainfall. This is similar to our study. SA Fattah [5] reported patients were admitted round the year, higher during July November. Rantakallio P et al [8] reported cases in month of May June and July. This discordant was may be due to regional variation.

In our study fever was the commonest symptoms in all groups with total incidence of $97.6 \%$ followed by irritability (80.9\%), refusal to feed $(80.9 \%)$, altered sensorium $(76.1 \%)$, headache (61.9\%), convulsion $(52.3 \%)$, parotid sweeling $(28.7 \%)$, lethargy $(11.9 \%)$. Predominance of common symptoms which overlap with other disease makes it difficult to pin point the diagnosis of meningoencephalitis. Similar features were reported by SA Fattah et al [5] neurological features (85\%), $6 \%$ with pulmonary, $7 \%$ with combined neurological and pulmonary and $2 \%$ with other features. 13. Swadron SP [13] studied that febrile illness signs and symptoms of neuroinvasive disease such as headache, delirium, coma or new onset seizures were common features of meningioencephalitis. Schutte CM, Van Der Meyden CH et al [14] reported that most 
common symptoms at presentation were fever in $77.5 \%$, impaired consciousness in $56.5 \%$ and seizures $55.1 \%$ cases. $52.3 \%$ had GCS of 11-15at presentation. According to Mustafa A et al[15] the most common clinical presentations were fever impaired consciousness, seizures, vomiting, behavioral changes, recent rash and recent history of seizures and respiratory tract infections. Steiner I et al[16] studied that generalized convulsions along with altered sensorium were significant findings in patient with viral encephalitis. Rantakallio P et al [8] shows fever in78\%, impaired consciousness in 57\%, seizures in 55\% and vomiting in $31 \%$ of cases. Higher incidence of neurological features in their study might be due to better identification of these features by the parents compared to our study where parents are not educated and fever was common complain. So incidence of fever was highest in our study.

Of all these signs observed temperature $>100.4 \mathrm{~F}$ was most common sign in $32(94.1 \%)$ children, followed by Meningeal sign in $52.3 \%$ children, GCS $<7(52.3 \%$ ), hypotension (50\%), focal neurological deficit (52\%), features of RTI (28.5\%) cases were found. Papilledema (26\%), bulging fontanels (19\%), weakness of the limbs (16.6\%) were other presenting features. GCS <7 (87.5\%), hypotention(87.5\%)were main signs who died. Suchett CM et al [14] reported $88 \%$ of patients with a GCS value of $>12$ had good neurological outcome, while $88 \%$ of these of these with a GCS value of $\leq 8$ had a poor outcome. Rantakallio P et al [8] reported that 52.3\% had a GCS of 11-15 at presentation, RTI in $25 \%$, neurological illness $19 \%$, papiledema $28 \%$, meningeal sign in $49 \%$ of cases.

On CSF study, cell count was found to be less than 50 /cumm in all patients who died and $56.3 \%$ of cases who survived. CSF sugar was found at $<40 \mathrm{mg} / \mathrm{dl}$ in $38 \%$ cases and $27 \%$ of cases were found protein value $>45 \mathrm{mg} / \mathrm{dl}$. According to Rantakallio $\mathrm{P}$ et al [8] CSF cell count 0-50/cumm in $41 \%$, CSF protein $>45 \mathrm{gm} / \mathrm{dl}$ in $22 \%$, CSF sugar $50-75 \mathrm{mg} / \mathrm{dl}$ in $60 \%$, in $9 \%$ cases. Viral markers were detected in $47.7 \%$ of cases. The cases who were died, al (100\%) had positive viral markers. Steiner I[16] observed the most common etiology of VE was enterovirus 71(42.1\%), followed by measles(21.1\%), vericella zoster virus (15.8\%), herpes simplex virus (10.5\%) and mumps(10.5\%).According to Fidan Jmor et al[17] the most commonly identified agents based on virological and serological studies were VZV (24 cases), mumps virus (8cases),HSV(7cases) and measles virus (4 cases).the aetiology remain unclear in 37 children(39\%cases). Rantalaiho et al [18] studied that in $<14$ yrs age group $38.1 \%$ had positive viral marker. Rautonen $\mathrm{J}$ et al[19]reported both anti-HSV IgG and IgM antibodies were positive in 3(27\%) of the 11 acute sera, where as a fourth sample was positive for anti-HSV IgG antibodies only. Simultaneously CSF analysis for HSV PCR was done within 5days of illness in 6 of these 11 patients and it revealed positive in $2(33 \%)$.

The different hematological parameters in meningoencephalitis in our study was serum CRP $>6 \mathrm{mg} / \mathrm{L}$ most frequent (47\%), followed by TLC $>11000 /$ cumm in $16.7 \%$ of patient and $\mathrm{Hb}$ $<10 \mathrm{gm} \%$ in $14.2 \%$ of patients. High abnormal LFT $(75 \%)$ and abnormal RFT $(87.5 \%)$ was found in cases who are died. Rantakallio P et al [8] shows that none of the hematological investigations revealed any significant trend. Serum Sodium was normal in $72.5 \%$ cases. TLC count $>11000$ in $47 \%$ of cases.

The CT and MRI brain abnormalities in meningoencephalitis show 75\% normal. Among abnormal finding swelling of the brain parenchyma was present in $10.7 \%$ and infarction in $14.2 \%$ cases. 
Rautonen J et al [19] showed that C T scan revealed unilateral or bilateral hypodensity in temporal lobe with or without involvement of other areas(frontal, parietal or occipital) in 8(57\%) of 14 patients. In 2(14\%) patients the abnormalities were confined to either frontal or occipitoparietal lobe. in those 1o patients, the initial CT scan done on days1-8 from onset of symptoms was normal (50\%). Hyper dense lesions of hemorrhage were observed in 6(60\%) patients. Follow up CT scan of brain in the chronic stage of disease done for 3 patients' revealed encephalomalacia and brain atropy. On MRI, done during the acute stage hyperintense signal (on T2-weighted images) and /or restricted diffusion abnormalities (on diffusion-weighted images) were seen in 10 (91\%) of 11 patients. These correspond to edematous changes in the temporal lobes in $8(73 \%)$, while in $2(18 \%)$ patients localization was either to fontal lobe or parietooccipital region. Only one of 11(9\%) MRI scan revealed no abnormality.

Out of 42 cases 8 (19\%) patient died, 6 (14.2\%) had some form of sequelae and 28(66.7\%) recovered completely. Mortality was highest in age group of 1-5 years. Wong V, Yeung CY [20] showed that the mortality rate was $28 \%$. Among the 41 survivors, $76 \%$ were completely normal and $24 \%$ had neurological sequelae with focal neurological deficit inv $29 \%$, personality changes in $6 \%$, moderate mental retardation in $2 \%$; severe mental retardation in $4 \%$, hyperactivity in $4 \%$ and epilepsy in $4 \%$. The best predictors to unfavorable outcome were rapid rate of detoriation in conscious level after admission and the age of the patients. According to SA Fattah et al [5] outcome of patients showed $74 \%$ recovery, $19 \%$ death, and $7 \%$ referral to higher center. Rantakallio P [21] reported in his study out of 147 cases, 24(16.3\%) died. For remainder at discharge, 48(32.7\%) had major sequelae, 19(12.9\%) had minor sequelae and 56(38.1\%) recovered completely. Of the major sequelae seen, the commonest was motor deficits in $26(17.6 \%)$ followed by seizures in 14(9.5\%) cases. Rautonen J et al [19] showed that the mortality rate of children with acute encephalitis is $3.8-28.04 \%$. a study done by American paediatric population by Doachowske J B[22] showed that $40 \%$ of children who recovered from acute encephalitis had persistent non-progressive neurological abnormalities.

Out of 34 cases who survived $6(17.6 \%)$ cases showed sequelae at the time of discharge. Motor incoordination was present in $2(5.8 \%)$ cases. seizure disorder behavioral disorder, deafness; cranial nerve palsy each was present in $1(2.9 \%)$ cases. Rantakallio P [21] showed that at discharge, $48(32.7 \%)$ had major sequelae, $19(12.9 \%)$ had minor sequalae and 56(38.1\%) recovered completely. Of the major sequelae seen, the commonest was motor deficits in $17.5 \%$, followed by seizures in $9.5 \%$ cases. The more common minor sequelae seen at discharge were subtle neurological deficit in $7.5 \%$ and behavioral changes in $2 \%$ cases.

In Clinical presentation of our study showed altered sensorium in 13(68.4\%) followed by convulsion \& meningeal sign each $8(42.1 \%$ ) of cases. in CSF study $>50$ cells count /cumm was found in $>50 \%$ of the group. CSF protein was high in both HZV 6(66.6\%) \& VZV 7(63.7\%) cases. Low CSF sugar was found in others 11(57.8\%) cases. Mustafa A., Salih M et al [15] showed that the commonest initial presenting symptoms and signs were fever (100\%), seizures (72\%), irritability (50\%) and weakness/ hemiparesis (39\%). Wong V et al [20] reported that CSF pleocytosis is usually present in about $97 \%$ of cases, it may be absent in either immunocompetent or immunocompromised, elevated protein levels (65\%) cases. 
The comparison of clinical parameters, CSF parameters between HSV \& VZV meningoencephalitis showed no statistically significant among both groups. According to Ugo K et al[23] nausea or vomiting $78 \%$ in HSV \& $50 \%$ in VZV neck stiffness $100 \%$ in HSV \& $38 \%$ in VZV. CSF Protein level is significantly high in patient with HSV type2 (median1205mg/dl) and in samples from those infected with ZVZ (median974mg/L). This is similar to our study.

Rantakallio P et al[8] shows that CSF cell count was significantly higher in patient with HSV-2 infection than in patients with enterovirus infection $(\mathrm{P}<0.01)$, and CSF protein levels were significantly higher in both patients with HSV-2 infection and patient with ZVZ infection. The CSF protein levels are significantly higher in CSF sample from patients infected with HSV type 2 and in sample from those infected with VZV.

The mortality in HSV was $58.5 \%$ which was highest, morbidity was $33.3 \%$. The common sequelae were motor incordination $4.7 \%$, deafness $8.3 \%$, seizures $8.3 \%$, and behavioral disorder $8.3 \%$. Our study is similar to the study done by Misra UK et al[24]. Rantakallio P et al [8] reported at the time of discharge $49 \%$ of patient either died or had major sequelae. This is in contrast with study by Rautonen et al [19] in which $9.5 \%$ of cases died or had severe damage. This discrepancy could be due to difference in race, etiological agent, the duration of illness at which the patient presented and inability of the family to afford tertiary care resulting in the patient being discharged once stabilized i.e. before optimum therapy. The latter limitation would make the patient appear worse off than those admitted for a longer period.

Among the different parameters studied, the incidence of GCS $<7$, intubation of with respiratory failure and duration of illness $>5$ days were statistically significant among survivors and died. Our study was in accordance with the study done by Kennedy et al [25]. Rautonen et al [19] found that history of an onset of greater than 3 days showed that an association with poor out comes.

\section{Summary}

Out of 42 cases $7 \%$ were infant, $48 \%$ were from $1-5 y e a r s$ and $45 \%$ were from 6-14 years age group. As regards to sex distribution $57.1 \%$ were male babies, $42.9 \%$ were female babies. Highest number of cases occurred in summer season (45.2\%). The common symptoms were fever $(97.6 \%)$ irritability $(80.9 \%)$, refusal to feed $(80.9 \%)$, vomiting $(80.9 \%)$, altered sensorium $(76.1 \%)$, headache $(61.9 \%)$, convulsion $(52.3 \%)$, parotid swelling $(28.7 \%)$, and lethargy $(11.9 \%)$. The common signs observed were fever in $94.1 \%$, meningealsign in $52.3 \%$, GCS $<7$ in $52.3 \%$, hypotension $50 \%$, focal neurological deficit $52 \%$, features of RTI in $28.5 \%$ cases. Other presenting features were papilledema in $26 \%$, bulging fontanales in $19 \%$ and weakness of limbs in $16.6 \%$ of cases. Cell count was found $<50 / \mathrm{cmm}$ in all patients who were died and $56.3 \%$ of cases who were survived. Viral markers were detected $47.7 \%$ of cases. The cases who died, all (100\%) had positive viral markers. On radiological assessment about $75 \%$ had normal finding. Among abnormal finding swelling of the brain parenchyma was present in $10.7 \%$ and infarction in $14.2 \%$ cases. $19 \%$ patient had died, $14.2 \%$ had some form of sequelae and $66.7 \%$ had complete recovery. Mortality was highest in age group of 1-5 years. HSV was common agent found among the positive viral marker detected cases. GCS $<7$ and Intubation had significant higher association with mortality. CSF protein was high in both HZV (66.6\%) \& VZV (63.7\%) cases. Gram stain and CSF culture was negative in all cases. 


\section{Conclusion}

Viral meningoencephalitis is a major health problem deu to high morbidity and mortality. Early diagnosis of disease is often difficult due to low incidence of disease specific signs. so early suspicion and a proper lumber puncture can only help in early diagnosis. Over the years mortality of viral meningoencephalitis have been substantially reduced inspite of major advance in treatment modalities. Thus prevention is main stay to reduce the mortality and morbidity. Better management and prevention of sequelae can be possible by early detection of complication by wider and prudent use of MRI and CT scan. The incidence and sequelae og meningoencephalitis deu to VZV and Mumps can be prevented by vaccination. Unavailability of specific diagnostic modalities to majority of children at remote unreachable places hinders formulating an effective treatment policy and adaption of preventable strategies. Detection of viral antibody is done by CSF IgM \& IgG. PCR method is suggested as a better option which has more sensitivity and specificity and gives a rapid diagnosis. Thus this can be useful in secondary care level also, from where majority of cases being refered and CSF viral culture facility is not available.

\section{References}

[1] Stahl JP, Mailles A, Dacheux L, Morand P. Epidemiology of viral encephalitis in 2011. Med Mal Infect 41: 453-464.

[2] Sejvar JJ. The evolving epidemiology of viral encephalitis. Curr Opin Neurol. 2006 Aug; 19(4):350-7.

[3] Rantalaiho T, Färkkilä M, Vaheri A, Koskiniemi M. (2001). Acute encephalitis from 1967-1991. J Neurol Sci. 184: 169-177.

[4] Long SS. Encephalitis diagnosis and management in the real world. Adv Exp Med Biol. 2011; 697:153-73.

[5] SA Fattah, SK Sarker, MY Ali, MT Alam, SY Ali. Profile Of. Clinically Suspected Encephalitis Patients Admitted To Faridpur. Medical College; Health Sci Bull 2004; 2:1-4. 40.9

[6] Perkins, D., Gyure, K.A., Pereira, E.F.R. et al. Journal of NeuroVirology (2003) 9: 101.

[7] DeBiasi RL, Kleinschmidt-DeMasters BK, Richardson-Burns S, Tyler KL. Central nervous system apoptosis in human herpes simplex virus and cytomegalovirus encephalitis. J Infect Dis. 2002 Dec 1; 186(11):1547-57. Epub 2002 Nov 11

[8] Rantakallio P, Leskinen M, von Wendt L. Incidence and prognosis of central nervous system infections in a birth cohort of 12,000 children. Scand J Infect Dis. 1986; 18(4):287-94.

[9] Sejvar JJ The evolving epidemiology of viral encephalitis. Curr Opin Neurol. 2006 Aug; 19(4):3507.

[10] Solomon T, Dung NM, Vaughn DW, Kneen R, Thao LT, Raengsakulrach B, Loan HT, Day NP, Farrar J, Myint KS, Warrell MJ, James WS, Nisalak A, White NJ. Neurological manifestations of dengue infection. Lancet. 2000 Mar 25;355(9209):1053-9

[11] Cochi SL, Fleming DW, Hightower AW, Limpakarnjanarat K, Facklam RR, Smith JD, et al. Primary invasive Haemophilus influenzae type $\mathrm{b}$ disease: a population-based assessment of risk factors. J Pediatr. 1986; 108(6):887-96.

[12] Chalrs G, Prober and Laurl Dyner. Meningoencephalitis in Kliiegman RM, Stanton BF, Schor NF, Geme III JW, Behrman RE. Nelson Text Book of Pediatrics 19ed. Elsevier publisors; 2012:25212523.

[13] Swadron SP. Pitfalls in the management of headache in the emergency department. Emerg Med Clin North Am. 2010 Feb;28(1):127-47. 
[14] Schutte CM, van der Meyden CH. A prospective study of Glasgow coma scale (GCS), age, CSFneutrophil count, and CSF-protein and glucose levels as prognostic indicators in 100 adult patients with meningitis. J Infect 1998; 37:112-5.

[15] Mustafa A. M. Salih, Heba Y. El Khashab, Hamdy H. Hassan, Amal Y. Kentab, Sara S. Al Subaei, Radwan M. Zeidan,Mohammed N. Al-Nasser and Saleh A. Othman . A Study on Herpes Simplex Encephalitis in 18 Children, Including 3 Relapses. Open Pediatr Med J. 2009;3: 48-57.

[16] Steiner I, Budka H, Chaudhuri A, Koskiniemi M, Sainio K, Salonen O, Kennedy PG. Viral meningoencephalitis: a review of diagnostic methods and guidelines for management. Eur J Neurol. 2010 Aug; 17(8):999-e57.

[17] Jmor F1, Emsley HC, Fischer M, Solomon T, Lewthwaite P. The incidence of acute encephalitis syndrome in Western industrialised and tropical countries. Virol J. 2008 Oct 30; 5:134.

[18] Rantalaiho T, Farkkila M, Vaheri A, Koskiniemi M. Acute encephalitis from 1967 to 1991. J Neurol Sci. 2001; 184:169-177.

[19] Rautonen J, Koskiniemi M, Vaheri A Prognostic factors in childhood acute encephalitis Pediatr Infect Dis J. 1991 Jun;10(6):441-6.

[20] Wong V, Yeung CY. Acute viral encephalitis in children. Aust Pediatr J 1987; 23:339—42.

[21] Rantakallio P, Leskinen M, von Wendt L. Incidence and prognosis of central nervous.... J Am Vet Med Assoc, Mar 22-29 1985; 253(12):1749- 1754.

[22] Beckham J, Tyler K. Mandell, Douglas, and Bennett's principle and practice of Infectious Diseases. 8th ed. Philadelphia: Elsevier's Saunders; 2016. Encephalitis. In: Bennett J, Dolin R, Blaser M, ed. by; pp. 1144-1152.

[23] Ugo K. Ihekwaba Goura Kudesia Michael W. McKendrick Clinical Features of Viral Meningitis in Adults: Significant Differences in Cerebrospinal Fluid Findings among Herpes Simplex Virus, Varicella Zoster Virus, and Enterovirus Infections. Clinical Infectious Diseases, Volume 47, Issue 6, 15 September 2008, Pages 783-789.

[24] Misra UK, Tan CT, Kalita J Viral encephalitis and epilepsy. Epilepsia. 2008 Aug; 49 Suppl 6:138.

[25] Kennedy PGE. Viral encephalitis. J Neurol 2005; 252:268-72.

*Corresponding author.

E-mail address: mangal74murmu@ yahoo.co.in 